\title{
Gender Differences Towards Gender Equality: Attitudes and Perceptions Of College Students
}

\author{
Carlos Ramos-Galarza ${ }^{1-4}$, Diego Apolo², Sonia Peña-García ${ }^{3}$, Janio Jadán-Guerrero ${ }^{4}$ \\ ${ }^{1}$ Facultad de Psicología, Pontificia Universidad Católica del Ecuador-PUCE, Quito, Ecuador \\ ${ }^{2}$ Universidad Nacional de Educación-UNAE, Azogues \& Universidad San Francisco de Quito-USFQ, Quito, Ecuador \\ ${ }^{3}$ Facultad de Comunicación, Lingüística y Literatura. Pontificia Universidad Católica del Ecuador-PUCE. Quito, \\ Ecuador \\ ${ }^{4}$ Centro de Investigación MIST. Universidad Tecnológica Indoamérica-UTI. Quito, Ecuador \\ Correspondence: Carlos Ramos-Galarza, Ph.D. Facultad de Psicología, Pontificia Universidad Católica del Ecuador, \\ Quito, Ecuador, Av. 12 de Octubre 1076 y Roca. Email: caramos@puce.edu.ec
}

Received: January 4, 2018 Accepted: January 18, 2018 Online Published: February 3, 2018

doi:10.5539/res.v10n1p61 URL: https://doi.org/10.5539/res.v10n1p61

\begin{abstract}
In this article we describe a research project where the objective was to analyze attitudes toward gender equality among male and female university students in Quito, Ecuador. The study methods included both quantitative and qualitative phases, and the results were then integrated. In the first stage of the research, we used inferential statistics to analyze differences in attitudes towards gender equality among 75 men and 75 women. In a next phase, we used constructivist qualitative methods to analyze the narratives of 22 subjects participating in three focus groups. In the quantitative phase, we found a statistically significant difference when comparing attitudes toward gender equality between the two groups of participants, where women were more favorable toward gender equality. In the qualitative phase we identified a common narrative theme in which women felt that they were in an unfavorable situation in terms of gender relations. In addition, a category emerged that described an awareness and a desire on the part of women to change this situation. Finally, we discuss the findings from previous research as well as theoretical aspects of gender equality.
\end{abstract}

Keywords: attitudes, gender equality, feminism, machismo, cultural practices, university students.

\section{Introduction}

Cultural practices are made up of "institutionalized norms for expression and participation, not only by the official culture, but also by other practices of popular culture" (Contreras, 2008, p. 7). In this sense, Aliaga (2015) proposes the existence of imaginary spaces of formation reinforced by social representations, understood as "a particular modality of knowledge, whose function is the production of behaviors and the communication between individuals"(Moscovici, 1979, p. 17) These are structured behaviors, attitudes, and forms of acting within society, and in the case of this study, the attitudes toward gender equality and inequality, as forms of social conditioning flowing from an androcentric, patriarchal mode of thinking.

These practices have established cultural phenomena that constitute and condition "forms of ritual and social conduct learned and transmitted from one generation to another" (Madrazo, 2005, p. 122); i.e., each day is marked by different interpretations of reality. This situation is evident in the social relations that mark the appropriate behavior in a community, where "the subjects represent roles, and on the other hand, offer concepts and images of themselves which need certain references"(Castillo et al. 2003, p. 39).

In the construction of different mental structures, similar emerging frameworks of intelligibility "are presented as a systematic configuration of properties that express differences objectively recorded in the conditions of existence in the form of systems of differential variations" (Bourdieu, 1988, p. 170), which generate in themselves unconscious attitudes, which are assumed to be natural and are legitimized by traditional forms of domination (Weber, 2006).

In this sense, there are similar contributions to the ideas on gender from research in Ecuador, (Camacho, 2006; Quintana, 2008; Aguirre, 2012; Basque, 2014; Baquerizo, 2014; Calderon, 2015; Quiroz, 2015; Bueno, 2017), that allow us to observe how cultural identity from the traditions, beliefs, and customs, make up a framework of intelligibility that guides the daily lives of participants in society. 
Worth mentioning also is that from the 1990s "gender studies introduced a relational approach according to which, we will only understand the experiences of men if these experiences are seen in relation to those of women and vice versa" (Martinez, 2005, p. 5). For this reason, it is necessary for us to contribute empirical evidence from psychological, sociological, and anthropological approaches in order to know the structure of these frameworks concerning gender equality that produce the young people in university training today (Mora \& Pujal, 2016).

This study deals with the category of gender as a "system of power that results from social conflict" (Barbieri, 1992, p. 152), which itself is part of the broader "historical and cultural social and symbolic construction of men and women on the basis of their sexual differences" (Hernandez, 2006, p. 1). These resulting norms remain in dispute so that tension frames their intelligibility, since the historical memory that has been naturalized and legitimized from their social and cultural backgrounds produces problems of conciliation among their personal, family, and work lives, causing some women to make a choice between family life and a professional career in the labour market" (Ferrer-i-Carbonell \& Ramos, 2014, p. 723).

Gender roles, understood as a social construction, push individuals towards an understanding of the group, thereby legitimizing "what is necessary to carry out the mediation of values, symbols, rules, and instrumental resources" (Herrera, 2000 , p. 44) that are consolidated from the family, the school, the State and religion. For example, the Church, as "a guarantor of the system, not only has the ecclesiastical jurisdiction to prosecute its members, but also the power to judge if civilians have violated the ecclesiastical provisions" (Masferrer, 2013, p. 195).

This is how cultural practices generate behaviors and form attitudes based on the environment in which people are involved, trying to "shape, form, or maintain men and women and their material conditions" with the aim of sustaining the established order (Castro et al., 1996, p. 35).

Therefore to speak from the perspective of gender is an effort to generate changes in the respective specificities, functions, responsibilities, expectations and opportunities for men and women (Martinez, 2007), thereby enabling them to reread and reinterpret the forms of social influence that contribute to the change of "perception, judgment, modes of thinking or acting of an individual" (Suria, 2012, p. 44).

By having knowledge of areas of agreement, dispute, and tension, we can develop proposals applicable to their contexts in regard to gender equality, and therefore allowus to understand that "speaking of gender means to separate the essential aspects that are attributed to people according to their anatomical sex (and all the meanings and practices that entails), whose process of construction has resulted in women being the less favoured participants in the social relations between men and women (Hernandez, 2006, p. 4)."

Finally, it is important to mention that gender equality aims to develop relations characterized by equanimity between the sexes (Fernández-Saez et al., 2016), where what is sought is equal opportunities and autonomy in the various social scenarios of coexistence between men and women, in addition to contributing to reflections on the impact of the inequality which is evidenced (De Barbieri, 1993; Woodend \& Devins, 2005; Hippisley-Cox et al., 2006; Mobarak \& Söderfeldt, 2010; Keleher, 2013).

Based on the previously described background, the question arises is their differences in the attitudes towards gender equality between male and female university students? To answer this question, our research team proposed a study based on a mixed approach in two phases. First, by using a quantitative approach, we sought to determine if there were statistically significant differences in the attitudes of university men and women toward gender equality. In a second phase, we analyzed the narratives that emerged in the discussions with the participants using qualitative methods.

\section{Materials and Methods}

\subsection{Research Design}

We use a mixed two-phase confirmatory research design. The first phase of the research was quantitative, and was descriptive rather than experimental, looking at attitudes and their correlates at the time of the interview. The second phase used a qualitative approach based on a constructivist epistemology, where, from the narratives and the symbolic interactions of the research participants, we were able to identify the meanings that they had constructed in relation to gender equality (Ramos-Galarza, 2015).

\subsection{Participants}

In the first phase, we worked with a purposeful sample of convenience (Casal \& Mateu, 2003; Alamino, et al., 2006) which comprised 150 college students belonging to the higher education system within Quito. It is important to mention that we don't intend to generalize our results; that what we sought was to establish contextual data that support the analysis toward the "characterization of social forms" regarding the topic.

The student's age range was between 17 and 32 years old ( $\bar{X}=20.85$ years; $s d=2.46$ years). The socioeconomic level of 
the participants was middle- and upper-middle class. In terms of gender, 75 (50\%) were men and $75(50 \%)$ were women. In the second phase, 22 university students with the same characteristics as mentioned previously participated in three focus groups that consisted of: (1) men only; (2) women only; and (3) men and women combined. The structuring of the focus groups relied on the contributions of Hernández-Sampieri et al. (2014) and Arroyave et al. (2016).

\subsection{Techniques and Instruments for Data Collection}

In the quantitative stage, we used a reactive psychometric questionnaire of attitudes toward gender equality prepared by De Sola, Martinez \& Melia (2003). This questionnaire consists of 30 items which allow the assessment of six factors: 1) aspects related to sexual orientation; (2) issues with religious symbolism; (3) values pertaining to partnership structure; (4) scope of attitudes relating to private factors; (5) scope of attitudes relating to public factors; and (6) sexuality and personal freedom. Each item was evaluated in a Likert scale of 1 to 7 points, where a higher score indicated a stronger attitude toward gender equality. The authors have reported a high value for Cronbach's alpha for the scale: $\alpha=91$. In the case of our research, after the respective scan was performed, we found an internal consistency coefficient of $\alpha=86$, which suggests that the instrument has an adequate reliability for application in this investigation. In addition, the correlation between the individual items and the total score was strong enough that we did not need to delete any item to improve the internal consistency coefficient.

In the qualitative stage we created three focus groups: one with seven women, another with seven men, and a third group which included four men and four women. Each focus group lasted approximately two hours. All the meetings were taped and transcribed for later analysis. In addition, we used field log notes where this information was recorded from the observation of the researchers.

\subsection{Analysis of Data}

For the quantitative phase we used descriptive statistics to represent summarize the data for each of the six factors. These statistics included measures of central tendency, percentage distributions, and dispersion. Student $t$ procedure was used to compare the differences between men and women in terms of their attitude towards gender equality. We performed all analyses using the SPSS statistical package, version 20.

For the qualitative phase, we analyzed the content of group discussions based on the comparison and iterative interpretation of narratives recorded in the focus groups, in order to identify categories that were emerging and being amplified by the participants. This qualitative analysis was performed on the program Atlas.ti, version 7 .

\subsection{Procedure}

We administered the quantitative instrument to groups of about 20 people each. Focus groups were conducted in groups of seven or eight subjects in a comfortable and distraction-free environment. At all times we followed the ethical standards for research on human subjects. All the of the university students consented voluntarily to participate in the study, their personal data was kept in absolute confidentiality, they were informed of the objectives of the research, and they were told that it was possible to withdraw from the study at any time that they might choose. Finally, the physical and psychological well-being of the subjects was monitored and protected at all times.

\section{Results}

\subsection{First Study: Quantitative Phase}

In Table 1 contains the descriptive statistics for each of the scaled values from the questionnaire of attitudes toward gender equality.

Table 1. Descriptive statistics

\begin{tabular}{lcccc}
\hline Variable & Minimun & Maximun & $M$ & $S D$ \\
\hline Aspects related to sexual orientation & 10 & 35 & 24,69 & 4,87 \\
\hline Aspects related to religious symbolism & 5 & 35 & 22,37 & 6,49 \\
\hline Values pertaining to partnership structure & 11 & 35 & 21,03 & 5,48 \\
\hline Private factors & 10 & 35 & 24,62 & 6,06 \\
\hline Public factors & 8 & 35 & 22,84 & 5,36 \\
\hline Sexuality and personal freedom & 5 & 35 & 22,92 & 6,73 \\
\hline
\end{tabular}


In comparing gender differences in attitudes towards gender equality, we found statistically significant differences for all six of the constructed variables, with men always presenting a lower score in these comparisons [see Table 2 for the calculations] . The study questionnaire also included an additional question to identify whether participants had prior knowledge about gender equality; 71 men and 74 women responded affirmatively, while 4 men and 1 woman said responded negatively.

Table 2. Comparison according to gender

\begin{tabular}{|c|c|c|c|c|c|c|c|c|}
\hline Variable & Gender & $N$ & $M$ & $S D$ & Standard Error & $t(d f)$ & $p$ & Effect Size \\
\hline \multirow{2}{*}{$\begin{array}{l}\text { Aspects related to sexual } \\
\text { orientation }\end{array}$} & Male & 75 & 23.87 & 5.55 & 0.64 & \multirow{2}{*}{$\begin{array}{l}-.2 .09 \\
(148)\end{array}$} & \multirow[t]{2}{*}{0.03} & \multirow[t]{2}{*}{0.17} \\
\hline & Female & 75 & 25.51 & 3.93 & 0.45 & & & \\
\hline \multirow{2}{*}{$\begin{array}{l}\text { Aspects related to religious } \\
\text { symbolism }\end{array}$} & Male & 75 & 20.41 & 6.65 & 0.77 & \multirow{2}{*}{$\begin{array}{l}-3.87 \\
(148) \\
\end{array}$} & \multirow[t]{2}{*}{$<0.001$} & \multirow[t]{2}{*}{0.30} \\
\hline & Female & 75 & 24.33 & 5.73 & 0.66 & & & \\
\hline \multirow{2}{*}{$\begin{array}{l}\text { Values pertaining to } \\
\text { partnership structure }\end{array}$} & Male & 75 & 19.92 & 5.50 & 0.63 & \multirow{2}{*}{$\begin{array}{l}-2.53 \\
(148)\end{array}$} & \multirow[t]{2}{*}{0.01} & \multirow[t]{2}{*}{0.20} \\
\hline & Female & 75 & 22.15 & 5.28 & 0.61 & & & \\
\hline \multirow[t]{2}{*}{ Private factors } & Male & 75 & 22.56 & 6.57 & 0.76 & -4.41 & \multirow[t]{2}{*}{$<0.001$} & \multirow[t]{2}{*}{0.34} \\
\hline & Female & 75 & 26.68 & 4.72 & 055 & (148) & & \\
\hline \multirow[t]{2}{*}{ Public factors } & Male & 75 & 21.84 & 5.47 & 0.63 & -2.32 & \multirow[t]{2}{*}{0.02} & \multirow[t]{2}{*}{0.19} \\
\hline & Female & 75 & 23.84 & 5,08 & 0.59 & (148) & & \\
\hline \multirow{2}{*}{$\begin{array}{l}\text { Sexuality and personal } \\
\text { freedom }\end{array}$} & Male & 75 & 21.45 & 7.03 & 0.81 & -2.73 & \multirow[t]{2}{*}{0.007} & \multirow[t]{2}{*}{0.22} \\
\hline & Female & 75 & 24.39 & 6.12 & 0.71 & (148) & & \\
\hline
\end{tabular}

\subsection{Second Study: Qualitative Phase}

In the narratives of women, we found attitudes associated with gender inequality experienced in previous generations which were balanced by an awareness of the generational paradigm shift towards equality of gender and reactions to sexual orientation. The narratives that emerged in the male group had to do with meanings related to the role of the man in the maintenance of the family and of women as responsible for the household, to the virginity of women and their beauty, to the freedom of men, and to the start of the changing paradigm towards gender equality. From the combined group of men and women, the main narrative that emerged was related to the exercise of power.

\subsubsection{Female Narratives}

\subsubsection{Gender Inequality in Previous Generations}

In the Ecuadorian context, until not long ago, gender inequality was common for both men and women through practices that were rooted in culture through beliefs and traditions. This was affirmed by three of the women participants who stated that men of a generation ago should be handled as if they were Kings: "my uncle just goes and sits and everything happens the way he says he wants it to be, as if women were only there to meet his needs". A related theme was reported by two other participants: "To be like my mother-in-law isto have the minor role to make decisions, and it is as I say, that the man is their Holy King". Not only was the woman relegated to situations of servile behavior, but she was also relegated to the background in the managing of the home.

The institutionalized system has been feeding mechanisms of domination that disadvantage women. For example, because he is the one who brought more to the economic development of their home, the man showed practices of psychological violence and refused to lose his power, as is evident from the roles and stereotypes which assign certain areas to males and females. As described by participant \#1, his narrative illustrates this situation: "my mom was always earning more money than my father, and that was always what my dad called me ('mom')". Psychological violence has as 
one of its consequences humiliating and offending the victim, questioning the victim's value as a human being. As it can be inferred from the narrative, the one who receives the violence is the woman, only because by being the main source of supply of economic resources, she comes into dispute with the system of control of the man. This resource is affirmed and naturalized through cultural traditions that make a social order, where there are stereotypes and roles that appoint the dominant function to the male and home care provider to the woman, which in many occasions may result in aggressiveness and justification of violent expressions.

\subsubsection{Awareness of the Paradigm Shift Towards Gender Equality}

Despite the existence and use of the historical mechanisms of oppression that have generated situations unfavorable to women, today a new social construction of what is meant by equality and equity for women and men is emerging. Change in cognitive structures stem from an awareness in the narrative that describes the awakening status of women into situations that may be contributing against these historical norms.

It is relevant to mention that we have been able to identify in the narratives of men and women new social processes that attempt to contribute towards gender equality, despite the fact that male-centric, patriarchal structures still remain, new generations are meeting with greater opportunities to share their experiences and points of view, in addition to the accompaniment of public policies that, even though they are not brought into daily practice, are a legal support that accompanies the transformation processes against these entrenched social norms. For example, this narrative from a female participant: "I am able to make my own decisions; if I want to stay at home instead of going to church, I do. To be either in the care of the children or to serve a man, for me that won't work either, I'm not a person who is submissive to a man and who should keep the home and be caring for the children".

\subsubsection{Reaction to Sexual Orientation}

In this category we noted a narrative that invites respect and acceptance of other sexual orientations; however, this acceptance arises masked with comments of rejection; as in claiming the possibility of coexistence, provided that there is no direct interaction. For example, in the narrative of participant \#3, we can interpret the meanings of the participants in terms of sexual orientation: "I respect them if they interact with lesbians, but not with me." As you can see, it is as though there is a discourse that invites acceptance and respect; however, in actual practice, not to honor it, as if there were a huge bridge between belief and behavior.

\subsubsection{Male Narratives}

\subsubsection{The man supports the family and the woman takes care of the house}

From the social model based on patriarchy, a man should be the one who has the financial responsibility for the home, relegating women to the fulfillment of all domestic activities. The narrative of focus group participant \#1 continues to reflect this statement when he mentions that "For the society in which we live, it is the man who keeps the family".

So, the construct of man in charge of the financial home and woman in the background for other types of behavioral activities within the home, has generated an inequity when valuing the contribution of men and women in the family where the woman is relegated to a charge of domestic worker, and the man in a superior hierarchical role. We can see the dominant meaning of the above statement in the narrative of participant \#5 when he says that "man arrives home after work and just wants to spend all the time in bed and women should take care of this, as well as cleaning, food, etc."

\subsubsection{As a man, I'd like to be the First}

We found in male narratives a requirement of virginity of women as a feature of their value as an individual, and a sense of resignation when the man is not the first in her sex life. This situation in turn generates an objectification of women, where they lose value by not being a virgin when they begin a relationship because it does not meet the stereotype of chastity in our society. In this sense, the participant \#2 says: "If I were such a man, I'd want to be the first in the sex life of a woman, but it is difficult to find a virgin woman" (as he demonstrated by raising the palms of the hands, lifting his shoulders, and making a gesture with his face as a confirmation that there really is no other option).

The narrative of participant \#3 recognizes that finding a virgin woman is like finding a treasure, "because most women are not so, and those who do not have this condition produce discomfort in men because if a woman is not a virgin then she does not conform to the social norms because one always wants to be the first, supposedly because the first man for the woman reminds her of him".

In the narratives there was an unspoken but implied theme that if a female was not truly a virgin, she could not deceive a man because non-verbal language would confirm the deceit. In addition, participant \#4expressed the idea that, "Indeed, I think that it is purely for pride that we expect women to be virgins, but no, it is not so much that non-virgins lose value... but simply that virginity is more valuable in women than in men". 


\subsubsection{She is Pretty or Nothing}

The myth of beauty is built around the female body where, if she is not within the stereotype of what we construct socially as someone beautiful, there is a rejection. Such is the case narrated by participant \#6, who says that "you go out to a nightclub and see a girl who seems pretty, you know, you imagine that you fall in love and you take here very where...; on the other hand, if you approach a girl and you say, no, this woman is ugly, you walk away".

In a sense, in this participant's narrative a woman emerges reified as an object to be worn, as if she were a piece of clothing or a piece within a collection, which should be rejected if she is not within the standards of beauty. Participant \#3highlights this statement when he states: "Women always catch you with their clothing, perfume, earrings, makeup". Participant \#5 says that when "one sees a well-dressed woman on the street with a dress and stuff, one gets excited," and participant \#6 states that "one is excited by a woman's physique", so that if a woman looks normal, it is possible to not be attracted to her, but she should look like the "fixed" object of beauty that society expects her to be, then a man can accept her as an attractive individual; otherwise he relegates her to a second level.

\subsubsection{The Man is Bred to be More Free}

The sense of gender inequality is not an isolated event, but one that is thought to have evolved throughout our social history, as part of the power relationship of the male over the female, where the latter have been characterized as the weaker sex, and thus as being responsible for the cleaning of the home, the care of children, among other unfavorable situations. In this sense, participant \#5 says that "men have been bred to be free, the debauchery in us is accepted; on the other hand, women are raised to be in the home, which means that they cannot go out to have fun".

So we can see that from the early stages of development the notion is born that it is suitable for men to have more rights of social interaction, unlike women, in whom freedom should be restricted, because "they should be home, moreover, because men are raised to be freer than women" (participant \#4).

\subsubsection{It Is the Man Who Takes the Sexual Initiative}

The objectification of women has been constructed not only with the paradigm of beauty, but she is also seen as an object of sexual gratification, where the man is the one who has the power and the woman should wait passively in a sexual act of male dominance, and from here beliefs emerge, such as those manifested by our participant \#2, who states that "women are more self-conscious, men are more instinctive and look at a woman's erotic points, but women always let us be us, while they always have to be a bit more prudent and must wait for what we do".

According to participant \#1, "men are more aroused than women, and thus have more needs" (participant \#1), which legitimates cultural practices where physiologically men needmore sexual activity, but when a woman demands or initiates the act of pleasure, she is seen as bad or she can be rejected because it is the man who has that privilege.

\subsection{A Paradigm Shift}

The focus group of men also produced a narrative that, while it tended towards machismo, it also takes expresses a slight consciousness towards the unfavorable situation of women in relation to men, and notes that this form of acting and this concept of women is a meaning that has been building throughout the social history. In this sense, participant \#2 says that "all this 'men need women' was more notorious in the past, for example, at the time my grandparents".

In this spark of initial awareness of the relationship between the sexes that we identified in the discussion among the participants, we saw a situation similar to when one is in a cave, completely in the dark, and someone lights a candle. For example, when participant \#1 lit up just a little in the discussion group, he mentioned a concept that then managed to shed light upon this hidden location, one that largely determines the behavior of men and women: "I think that these ideas come from our parents, where women should be at home and for the man to go to his work. But already things have changed and it is no longer so; now women already assume that role, that that they should not just serve to home, children, food, and that sort of thing. They now have new goals, where they can contribute economically to the home, find a good job, be stable..."

In the current male discussions, we begin to see an incipient change to becoming aware of the dialectical connotation of the world in which we live, where meanings emerge as "the society is already changing, it is not like before, that women should be in the house"(participant \#5).

In addition, already taking into account the situation of symbolic violence between men and women, we can see that this is not an isolated construct that is created or that must be observed, but rather, it is a product of the historical interaction, where it is already understood that, "everything depends on the parenting that a man has received in his childhood"(participant \#3). Therefore, although very imbedded meanings of gender inequality were observed, we also identified an initial awareness of these inadequate power relations. 


\subsection{Mixed Narrative}

It is noteworthy that within the male and female narratives of the joint focal group, we can see that the interaction between men and women allowed a new concept to take shape, which is related to the exercise of power within the gender relationships.

\subsubsection{Exercise of Power}

There is an expression of discomfort in the narratives of women that takes the form of a complaint concerning the position of power that is assumed by men in work and within family life, where the views and decisions of women are relegated to a lower level. The joint working group participant \#2, a woman, highlights this concept: "Men believe that they have the power and we reinforce that in them". Accordingly, females participate in the maintenance of the power of the masculine side, generating a feeling among the participants that women in general are partly responsible, and perhaps even more guilty, that men assume roles of power in relationships with them. Thus, as participant \#4 puts it, "Just like when children are small, mothers send their children to grow up with other women".

Thus, a kind of rebellion against the male forms of oppression seems necessary, and it is even said openly, as outlined by males participating in a wider discussion that included other elements that contribute to the analysis of this type of power struggle between men and women, which clearly provoked female responses. During their private lives at home with their life partner, women begin to show their discomfort, however, and as participant \#1 expressed, "women who have been confined to the house make us believe that no, no more", against which the participant \#3 answers: " while that is true, in my house my dad says the last word, but who directs things and who has made the decisions is my mommy". This created the effect of revelation for the group that caused a collective laugh, as if everyone understood the meaning of such a statement. However, the women insisted on maintaining their initial position on the complaint that they shared, that despite their struggle to position themselves against then, it is still men who appear as the central figure in the family dynamics in economic decisions, the lives of the children, and in general on the most important family issues.

\section{Discussion and conclusions}

In the present study, we sought to analyze attitudes towards gender equality among university students through a mixed, two-phase approach for the research design, first quantitative and subsequently qualitative (Hernández-Sampieri et al., 2014; Vasilachis 2007; Sautu et al., 2005), which allowed for the measurement and research of beliefs, customs, and practices on gender equality.

In the quantitative phase we observed that in dimensions related to sexual orientation, religious symbolism, partnership structure, scope of the private and public factors, and sexuality and personal freedom, women had a greater tendency towards gender equality compared with the scores obtained by males.

These results are consistent with social representations that form the imaginary (Moscovici, 1979) that were identified in the narratives of the qualitative phase, where it was clear that, for the reality in which they operate, men and women are attached to the male from a collective point of view, while in their private lives the feminine is seen as a neglected form of coexistence, submissive to the male and maintaining the hegemonic, androcentric order that predominates in Western societies (Arendt, 2009; Stolke, 2004).

In this regard, the participation of women in public roles, for example, such as access to education, professional development, generation of economic resources, among others, has led to the transition of female identity (Rocha, 2013), which implies that they are beginning to assume, with their new gender identity, forms of empowerment and conquests that often come into tension with the cultural practices that have been seen as the natural roles of men and women.

This is one of the reasons why women's social movements have proposed the concept of empowerment, which aims to redefine what is considered feminine (García, 2003). In the words of Lagarde (2005), when integrating the definition of female empowerment, you can build new subjective and social settings in which there is an equitable relationship between the genders. Thus, it could be through this process in which women participate, and demand to establish gender equality, precisely because they have been historically disadvantaged and oppressed by patriarchal norms (Hernández, 2006).

The quantitative results presented here agree with recently published reports; for example, a study conducted by Fernandez-Saez et al. (2016) asserts that there is a significant gender inequality in Spain in recent years, with women having a more unfavorable situation in relation to men; for Saudi Arabia, Mobarak et al., (2010) note that gender inequality has led to cultural practices where men have strict roles that women cannot perform because they are financially dependent, so that women are relegated to only perform tasks for the household or for child-rearing; in United Kingdom, women were reported to have greater limitations for access to health services (Hippisley-Cox et al., 2006); in Canada, women have higher rates of stress, depression, anxiety and poorer quality of life (Woodend \& Devins, 2005); in Sweden, women receive a salary between $10 \%$ and $20 \%$ lower for work that is equal to that performed by men, despite having equal academic training; in Mexico, Ortega et al. (2012), carried out an analysis of the reports by the International 
Labour Organization (ILO) on gender equality, where they found that women's right to work is violated during their productive life time by instability, lack of decent jobs, and lower wages.

Even in Spain, Bas-Peña, Pérez de Guzmán \& Vargas-Vergara (2014) were able to identify within levels of education there is "an educational gap in education for equality" by gender (p. 116), seen at all educational levels, which goes hand in hand with the findings of our research, where, despite assuming implied gender equality, it is evident both in speech and in behavior that there are large contradictions. This is a response to cultural forms mentioned by Madrazo (2005) where the transmission of customs and values flow from the influence of the traditions that are responsible for words that permeate and our natural in speech from the logic of symbolic domination posed by Bourdieu (2000) and legitimated by institutions that are in charge of maintaining the structure.

In South America is no different from the ones just described, since we live in a similar situation where indigenous women live in an unfavorable state of deprivation in achieving a formal education, specialized medical care, fair wages, and a good opportunities in life (Razavi, 2016).

As you can see, in today's society there is a situation of gender inequality where the woman is the victim of this unequal relationship of power system. This situation is striking, since the quantitative phase of this study found that $96 \%$ of the sample respondents reported that they had learned about gender equality. However, when we analyze the attitude towards this issue, there is a contradiction, since it would seem that in their speech, almost all males claim to have knowledge of gender equality, but in their subjective and relationship practices, both in the public sphere and the private, this construction is not really so.

In this sense, Fernandez-Saez et al. (2016) claim that, while there are contexts where gender equality laws have been created, these are still on paper and in politically correct speech, because men still fail at the point of practice and real social change, which is consistent with our findings, since when we asked all of the study sample if they knew about gender equality, the vast majority of the participants stated positively, however, to really appreciate their position towards gender equality, this figure is distorted, not only in numbers, also in their narratives.

Several categories emerged in the qualitative phase allowing us to understand the quantitative data with greater value. The first meaning that emerged was related to gender inequality in previous generations, situations which can be understood in the context of the patriarchal society, which coerce woman towards a private life of servitude, and therefore they are seen as a body for the use of others, subjected to male dominance or to procreation. Symbolically, this situation in life that is given to the woman is not considered as a social subject, as stated by Lagarde (2005), but as an object that does not belong to her, but to others. Therefore the control of home falls to males based on their roles that are assumed as naturally legitimized by the community and by the acceptance of such control by the women and the children.

Another meaning that emerged in the narratives has to do with awareness of the new paradigm of women seeking gender equality that, according to Guarderas (2015), has to do with a situation where women produce a sort of light that shines into the darkness, where the narrative expressing an awareness of oppression becomes a tool to act in favor of the pursuit of equal gender rights.

This female consciousness, identified in the narratives and in the highest scores obtained in the disposition towards gender equality, has a relationship to that which is affirmed by Valenzuela (2016), who notes that along with our social construction, unequal power relations have existed where the woman has fulfilled the role of the dominated, asit has been in the current historical context, where to become aware of the need for a change in search of equitable gender relations, societies will benefit from the contributions of women with new areas that are now beginning to arise for them which will allow new forms of relationships between the genders by changing mentalities, accepting differences, eliminating mechanisms of exclusion, and prioritizing values of cooperation and equality. This does not mean that women have achieved equality, which remains an aspiration and why we must continue investigating and proposing areas of debate and social arrangements (Lagarde, 2012).

While the design of our methods controlled most of the variables that might interfere with the results, it is important to mention several limitations that should be considered. Firstly, for the quantitative phase, the sample was not representative of people at the national level, and was only constructed in one city of Ecuador, which produces results that can be interpreted locally. However, this situation encourages us to cover a larger population of our country in our next research project.

And, secondly, in the qualitative phase there could have been a situation of subjective influence on each participant and on the researchers of this study that moves us away from a constructivist ontology, so that the situation described in this article is only a product of the symbolic interactions of all those who participated in some way in the research.

Future research topics that emerge from this study include, among others, analysis of that portion of the study dealing with the unfavorable gender equality practices perceived by the masculine gender; analysis of the objectification of women in 
trade magazines and advertising in Ecuador; and intervention studies where one can increase awareness of the attitudes and acts of unfair power relationship between men and women.

Finally, it is important to mention that this article has sought to analyze the situation of gender equality in colleges, and that this analysis invites us to reflect on the power relationships in the broader society in which we live day to day, and to see within this larger population the construction of the reality of the professional future on gender equality. Our results do not seek to impose an absolute truth, but rather to lead to a reflection in order to make possible a better coexistence between men and women.

\section{Ethical Approval}

This research was approved by the ethics committee of the Technological Indoamérica University of Ecuador. All procedures performed were in accordance with the 1964 Helsinki declaration and its later amendments or comparable ethical standards.

\section{References}

Aguirre, M. (2012). La idealización del cuerpo femenino a través de la mirada masculina. Caso de estudio: la revista SOHO (Master's Thesis). Universidad Andina Simón Bolívar, Quito-Ecuador.

Alamino, A., Costa, \& Castejón, J. (2006). Elaboración, análisis e interpretación de encuestas, cuestionarios de escalas de opinión. Alicante: Marfil.

Aliaga, F. (2015). Comentarios en torno a los imaginarios y representaciones sociales. Estudios Bolivianos, 23, 83-191.

Arroyave, D., Londoño, S., Valencia, N., Jalloh, C., Wylie, J., \& Arbeláez, C. (2016). Grupos focales de discusión: estrategia para la investigación sobre salud sexual con adolescentes con experiencia de vida en calle en Medellín, Revista Facultad Nacional de Salud Pública, 34(3), 285-296. https://doi.org/10.17533/udea.rfnsp.v34n3a03.

Arendt, H. (2009). La Condición Humana. Barcelona: Paidós.

Baquerizo, E. (2014). La mujer invisible: producción y reproducción en el agro de la costa interior ecuatoriana (Master's Thesis). FLACSO Sede Ecuador, Quito.

Camacho, M. (2006). Las políticas del cuerpo y las negociaciones identitarias de las travestis en el ex penal García Moreno (Master's Thesis). Universidad Andina Simón Bolívar, Ecuador.

Bas-Peña, E., Pérez-de-Guzmán, V., \& Vargas-Vergara, M. (2014). Educación y género. Formación de los educadores y educadoras sociales. Pedagogía Social, (23), 95-120. https://doi.org/10.7179/PSRI_2014.23.05

Bourdieu, P. (1988). La distinción. Madrid: Taurus.

Bourdieu, P. (1999). Razones Prácticas. Sobre la Teoría de la Acción. Barcelona: Anagrama.

Bourdieu, P. (2000). La Dominación Masculina. Barcelona: Anagrama.

Bueno, A. (2017). Estéticas curvas para una revolución artístico-feminista. AusArt Journal for Research in Art. 5(1), 91-101. https://doi.org/10.1387/ausart.17793

Casal, J., \& Mateu, E. (2003). Tipos de muestreo. Rev. Epidem. Med. Prev, 1(1), 3-7.

Castillo, R., Patiño, M., Pesántez, B., \& Ortiz, A. (2003). Incidencia de la emigración en la construcción de la identidad y proyecto de vida de los jóvenes. Cuenca: U Ediciones.

Castro, P., Chapman, R., Gili, S., Lull, V., Micó, R., Rihuete, C., \& Sanahuja, M. (1996). Teoría de las prácticas sociales. Complutum, (2), 35-48. https://doi.org/10.4067/S0717-554X2017000200221

Contreras, R. (2008). Análisis crítico de la cultura. Prácticas culturales, Revista Contribuciones a las Ciencias Sociales. In: http://www.eumed.net/rev/cccss/0712/rcs4.html.

Cortés, A., Pérez, D., Aguilar, J., Valdés, M., \& Taboada, B. (1998). Orientación sexual en estudiantes adolescentes. Revista cubana de medicina general integral, 14(5), 450-454.

De Barbieri, T. (1993). Sobre la categoría género. Una introducción teórico-metodológica. Revista Debates en Sociología, (18), 147-178.

De Sola, A., Martínez, I., \& Meliá, J. (2003). El cuestionario de actitudes hacia la igualdad de géneros (CAIG): elaboración y estudio psicométrico. Anuario de Psicología, 34(1), 101-123.

Fernández-Sáez, J., Ruiz-Cantero, M., Guijarro-Garvi, M., Rodenas-Calatayud, C., Martí-Sempere, M., \& Jiménez-Alegre, M. (2016). Tiempos de equidad de género: descripción de las desigualdades entre comunidades autónomas. España 2006-2014. Gaceta Sanitaria, 30(4), 250-257. https://doi.org/10.1016/j.gaceta.2016.03.015 
Ferrer-i-Carbonell, A., \& Ramos, X. (2014). Inequality and Happiness. Journal of Economic Surveys, 28(5), 1016-1027. https://doi.org/10.1111/joes.12049

García, B. (2003). Empoderamiento y autonomía de las mujeres en la investigación sociodemográfica actual. Estudios demográficos y urbanos, (53), 1-34.

Guarderas, P. (2015). Tramoyas, personajes y tramas de la actuación psicológica en la violencia de género en Quito. Universitas Psychologica, 14(5), 1569-1581. https://doi.org/10.11144/Javeriana.upsy14-5.tpta

Hernández-Sampieri, R., Fernández-Collado, C., \& Baptista, L. (2014). Metodología de la Investigación. México D.F.: Mc Graw Hill.

Hernández, Y. (2006). Acerca del género como categoría analítica. Nómadas, 13(1), 1-11.

Herrera, M. (2000). La relación social como categoría de las ciencias sociales. Reis: revista española de investigaciones sociológica, (90), 38-42.

Hippisley-Cox, J., Yates, J., Pringle, M., \& Hammersley, V. (2006). Sex inequalities in access to care for patients with diabetes in primary care: questionnaire survey. The British Journal of General Practice, 56(526), 342-348.

Keleher, H. (2013). Policy scorecard for gender mainstreaming: gender equity in health policy. Australian and New Zealand Journal of Public Health, 37(2), 491-492. https://doi.org/10.1111/1753-6405.12027

Lagarde, M. (1996). Género y Feminismo. Desarrollo Humano y Democracia. Madrid: Horas y Horas.

Lagarde, M. (2005). Los cautiverios de las mujeres: madresposas, monjas, putas, presas y locas. México D.F.: Universidad Nacional Autónoma de México.

Lagarde, M. (2012). El feminismo en mi vida. Hitos, claves y utopías. México D.F.: Instituto de las Mujeres del Distrito Federal.

Madrazo, M. (2005). Algunas contribuciones en torno al significado de la tradición. Contribuciones desde Coatepec, (9), $115-132$.

Martínez, I. (2007). Actualización de conceptos en perspectiva de género y salud. Programa de Formación de formadores/as en perspectiva de género en salud. Materiales didácticos. Ministerio de sanidad y Consumo. In:http://www.msssi.gob.es/organizacion/sns/planCalidadSNS/pdf/equidad/03modulo_02.pdf.

Masferrer, E. (2013). Los ritos de paso y su incidencia en el campo religioso mexicano. Cuicuilco, 20(57), 191-205.

Mobarak, A., \& Söderfeldt, B. (2010). Gender inequity in Saudi Arabia and its role in public health. Eastern Mediterranean Health Journal, 16(1), 113-118.

Mora, E., \& Pujal, M. (2016). Los fines de la formación universitaria desde una perspectiva de género. Convergencia Revista de Ciencias Sociales, 23(70), 143-176. https://doi.org/10.29101/crcs.v23i70.3810

Moscovici, S. (1979). El Psicoanálisis su Imagen y su Público. Buenos Aires: Huemul.

Ortega. A., González, S., Chávez, M., \& Sánchez, A. (2012) .Propuesta para la Medición de la Vulnerabilidad Laboral según las Regulaciones de Trabajo Decente de la Organización Internacional del Trabajo (OIT). México D.F.: Instituto Nacional de las Mujeres.

Quintana, M. (2008). Sexo seguro, cuerpos disciplinados. (Tesis de maestría). FLACSO sede Ecuador. Quito.

Quiroz, N. (2015). Transformaciones históricas de la subjetividad de mujeres profesionales de clase media y sus imaginarios del amor romántico. (Master's Thesis), FLACSO Sede Ecuador, Quito.

Ramos-Galarza, C. (2015). Los paradigmas de la investigación científica. Avances en Psicología, 23(1), 9-17.

Razavi, S. (2016). El progreso de las mujeres en el mundo 2015-2016. Washington D.C.: ONU Mujeres.

Rocha, T. (2013). Mujeres en tiempo de cambio: retos, obstáculos, malestares y posibilidades. In Mujeres en transición: reflexiones teórico-empíricas en torno a la sexualidad, la pareja y el género, T. Rocha \& C. Cruz (eds.), 243-272. México D.F.: Universidad Iberoamericana.

Rocha, T., \& Cruz, C. (2013). Introducción. In Mujeres en transición: reflexiones teórico-empíricas en torno a la sexualidad, la pareja y el género, T. Rocha \& C. Cruz (eds.), 9-16. México D.F.: Universidad Iberoamericana.

Sautu, R., Boniolo, P., Dalle, P., \& Elbert, R. (2005). Manual de metodología: construcción del marco teórico, formulación de los objetivos y elección de la metodología. Buenos Aires: CLACSO.

Stolke, V. (2004). La mujer es puro cuento: the culture of gender. Revista Estudos Feministas, 12(2), 77-105. https://doi.org/10.1590/S0104-026X2004000200005 
Suriá, R. (2012). Guía de Recursos Didácticos de Psicología Social. , Alicante: Editorial Club Universitario.

Valenzuela, M. (2016). Las bases epistémicas de la concepción feminista de la ciudadanía. Revista Estudos Feministas, 24(1), 31-43. https://doi.org/10.1590/1805-9584-2016v24n1p31

Vasilachis, I. (2007). Estrategias de Investigación Cualitativa. Buenos Aires: Gedisa.

Vasco, D. (2014). Imaginarios de belleza femenina de las estudiantes de comunicación social y periodismo en dos universidades de Quito (Master's Thesis). Universidad Andina Simón Bolívar, Quito-Ecuador.

Weber, M. (2006). Conceptos sociológicos fundamentales. Madrid: Alianza Editorial.

Woodend, A., \& Devins, G. (2005). Gender of the care environment: influence on recovery in women with hearth disease. Canadian journal of cardiovascular nursing, 15(3), 21-31.

\section{Copyrights}

Copyright for this article is retained by the author(s), with first publication rights granted to the journal.

This is an open-access article distributed under the terms and conditions of the Creative Commons Attribution license (http://creativecommons.org/licenses/by/4.0/). 